\title{
Matrix metalloproteinase-2 and angiotensin-1 gene polymorphisms in patient who have coronary artery disease
}

\author{
Koroner arter hastalığı olan hastalarda matriks metalloproteinaz-2 ve anjiyotensin-1 \\ gen polimorfizmleri
}

Kadri Gökçe, Ramazan Sabırlı, Aylin Köseler, İbrahim Türkçüer, Atakan Yılmaz

Gönderilme tarihi:24.02.2021

Kabul tarihi:03.06.2021

\begin{abstract}
Introduction: The rupture of atherosclerotic plaques is caused by the impact of matrix metalloproteinases (MMPs) upon the local fibrous valve and so might convert a chronic disease to a myocardial infarction, ultimately leading to instant death. Angiotensin converting enzyme (ACE) is actively engaged in the pathogenesis of ischemic heart disease. This study tries to unravel whether/how ACE and MMP-2 gene polymorphism contributes to the occurrence of Coronary Artery Disease (CAD).

Materials and methods: A total of 300 individuals (100 healthy/200 patients) were included in the study. A PCRRFLP method was utilized for ACE gene I/D and DNA sequencing MMP-2 (-1306 C/T) polymorphisms.

Results: The ACE-1 gene D/D, I/D and I/I genotype frequency of the CAD cohort was $50 \%, 29 \%$, and $21 \%$, respectively whereas that of the healthy control cohort was $37 \%, 45 \%$ and $18 \%$, respectively. Our findings indicate that the groups differed significantly in relation to the ACE-1 genotypes $(p=0.021)$. The frequencies of ACE-1 gene allele $I$ and $D$ in both cohorts did not reveal a significant difference $(p=0.314)$. In addition, the two groups did not manifest MMP-2 (rs243865) gene polymorphism.

Conclusion: The association between MMP-2 gene polymorphism and CAD is too weak to suggest a conclusive evidence. The I/D genotype frequency remained higher in the healthy individuals than in the CAD cohort, while in the CAD group D/D genotype was more frequently than control group. Finally, the patients with D/D genotype tend to bear greater risk for cardiovascular diseases.
\end{abstract}

Key words: MMP-2 gene polymorphism, ACE-1 gene polymorphism, coronary artery disease, Turkish population.

Gokce K, Sabirli R, Koseler A, Turkcuer I, Yilmaz A. Matrix metalloproteinase-2 and angiotensin-1 gene polymorphisms in patient who have coronary artery disease. Pam Med J 2022;15:29-36.

Öz

Giriş: MMP'lerin lokal fibröz kapak üzerindeki etkisi aterosklerotik plakların kopmasına yol açar ve sonuç olarak kronik bir hastalığı akut miyokard enfarktüsüne çevirerek ani ölüme sebep olabilir. ACE (Anjiotensin dönüştürücü enzim)'nin çeşitli biyolojik eylemleri iskemik kalp hastalığının patogenezinde yer alır. Bu nedenle biz de çalışmamızda anjiotensin converting enzim (ACE) ve matrix metalloproteinaz 2 (MMP-2) gen polimorfizminin $\mathrm{KAH}$ gelişimindeki rolünü değerlendirmeyi amaçladık.

Gereç ve yöntem: Çalışmaya toplamda 300 gönüllü (100 sağlıklı/200 hasta) dahil edildi. ACE gen I/D için PCRRFLP yöntemi ve MMP-2 (-1306 C/T) polimorfizmi için DNA dizi analizi yöntemi uygulandı.

Bulgular: Gruplar arasında ACE-1 genotiplerine bakıldığında CAD grubunda D/D genotip frekansı \%50, I/D genotip frekansı \%29, I/I genotip frekansı \%21; kontrol grubunda D/D genotip frekansı \%37, I/D genotip frekansı $\% 45,1 /$ genotip frekansı \%18 olarak saptanmıştır. Gruplar arasında ACE-1 geni genotipi açısından anlamlı fark mevcuttur $(p=0,021)$. CAD grubunda ise D/D genotip frekansı kontrol grubuna göre daha yüksektir. ACE-1 geni alleli sayılarına bakıldığında her iki gruptaki I ve D allel frekansları benzerdir ve istatistiksel olarak anlamlı fark mevcut değildir ( $p=0,314)$. Buna ek olarak, iki grup MMP-2 (rs243865) gen polimorfizmi göstermedi.

Sonuç: Bu çalışma MMP-2 (rs243865) gen polimorfizmi ile koroner arter hastalığı arasında bir ilişki olmadığını göstermiştir. I/D genotip frekansı kontrol grubunda KAH grubuna göre daha yüksek, D/D genotip frekansı ise $\mathrm{KAH}$ grubunda kontrol grubuna göre daha yüksekti. D/D genotipli hastalarda KAH hastalığı riski artmıştır.

Kadri Gökçe, M. D. Department of Emergency Medicine, Elazig Fethi Sekin City Hospital, Elazig, Turkey, e-mail: drkadri_gokce@hotmail.com (https://orcid.org/0000-0002-1083-0599)

Ramazan Sabırlı, M. D. Department of Emergency Medicine, Medical Faculty, Kafkas University, Kars, Turkey, e-mail: ramazan.sabirli@deu. edu.tr (https://orcid.org/0000-0003-4599-5833)

Aylin Köseler, Assoc. Prof. Department of Biophysics, Pamukkale University Medical Faculty, Denizli, Turkey, e-mail: akoseler@pau.edu.tr (https://orcid.org/0000-0003-4832-0436)

İbrahim Türkçüer, Prof. Department of Emergency Medicine, Medical Faculty, Pamukkale University, Denizli, Turkey, e-mail: iturkcuer@pau. edu.tr (https://orcid.org/0000-0001-8342-4615) (Corresponding Author)

Atakan Yılmaz, Assoc. Prof. Department of Emergency Medicine, Medical Faculty, Pamukkale University, Denizli, Turkey, e-mail: dr atakanyilmaz@yahoo.com (https://orcid.org/0000-0002-9773-5681) 
Anahtar kelimeler: ACE-1 gen polimorfizmi, MMP-2 (rs243865) gen polimorfizmi, Türk populasyonu, koroner arter hastalığı.

Gökçe K, Sabırlı R, Köseler A, Türkçüer İ, Yılmaz A. Koroner arter hastalığı olan hastalarda matriks metalloproteinaz-2 ve anjiyotensin-1 gen polimorfizmleri. Pam Tıp Derg 2022;15:29-36.

\section{Introduction}

As proteolytic enzymes, matrix metalloproteinases (MMPs) can degrade the extracellular matrix components responsible for regeneration of the connective tissue in regular biological events [1, 2]. The rupture of atherosclerotic plaques is caused by the impact of matrix metalloproteinases (MMPs) upon the local fibrous valve and so might convert a chronic disease to a myocardial infarction, ultimately leading to instant death [2]. Vascular remodeling is a determinant of main vascular pathologies, such as atherosclerosis and restenosis, and the regulation of the MMP system is commonly acknowledged to be key to vascular remodeling and atherosclerosis [3]. Smoking, diabetes mellitus, homocysteine, and elevated lipid levels are known as the major drivers of oxidative stress in blood vessels, thereby activating MMPs [4]. One possible candidate gene closely linked with coronary artery disease (CAD) is MMP-2 (also called gelatinase A), whose main function is the hydrolysis of gelatin and type IV collagen $[4,5]$.

Various pathways of angiotensin converting enzyme (ACE) are actively engaged in the pathogenesis of CAD [6, 7]. Activation of angiotensin I and bradykinin inactivation lead to decreased tissue perfusion [8]. Furthermore, the induction of angiotensin-induced plasminogen activator inhibitor causes CAD, creating occlusive coronary thrombus formation [8, 9]. In addition, the stimulation of angiotensininduced growth is involved in the pathogenesis of cardiac hypertrophy and ventricular remodeling [10]. Serum and tissue ACE levels are closely linked with the insertion/deletion (I/D) polymorphism in the ACE gene. In persons with homozygous $D$ alleles at the angiotensin II level, the lack of 287 base pairs in the $16^{\text {th }}$ intron of the ACE gene in the chromosome 17 is higher than those with the heterozygous or homozygous allele. The effects of ACE gene polymorphism on cardiovascular diseases were studied previously, and the relationship between left ventricular hypertrophy and ACE gene polymorphism is widely recognized by scholars.
Accordingly, the fact that the left ventricle and heart mass are larger in individuals with $D / D$ genotype is well-established and empirically confirmed. The association between HT and ACE gene polymorphism has also come under close scrutiny [2, 11-13]. Previous research findings on ACE gene polymorphism have suggested that it may act as a genetic marker in the development of various cardiovascular diseases, yet these studies have yielded inconsistent and contradictory results thus far [8, 14-20]. Against this background, this study tries to unravel whether/how ACE and MMP-2 gene polymorphism contributes to the occurrence of Coronary Artery Disease (CAD).

\section{Materials and methods}

This prospective study tried to explore matrix metalloproteinase 2 and angiotensin converting enzyme gene polymorphism in patients with ischemic heart disease. This clinical trial was performed in the Emergency Department of Faculty of Medicine in Pamukkale University between January 1 and December 31, 2018.

Prior to the study, the approval was granted from Pamukkale University Non-Invasive Clinical Research Ethics Committee (with the decisions of the Board of Directors numbered 05, dated 06.03.2018). The informed consent form was obtained from all of 300 subjects (100 healthy control group and 200 patients aged between 18 and 91) in accordance with the Helsinki Declaration.

\section{Selection of participants}

\section{Inclusion criteria}

- Diagnosis of CAD of patients included in the patient group

- $\quad$ The control group's being healthy and having low risk in terms of risk classification

- Being over 18 years old

\section{Exclusion criteria}

- The presence of any heart disease other than $C A D$ in the patient group 
- $\quad$ The presence of any cardiac disease or CAD in the control group

- $\quad$ Being under 18 years old

\section{Genomic DNA isolation}

The standard phenol-chloroform isolation method was utilized to isolate the genomic DNA from peripheral blood, and the resulting DNAs were stored at $-20^{\circ} \mathrm{C}$.

\section{Analysis of ACE gene polymorphism}

ACE gene I/D polymorphism was investigated through the PCR-RFLP method, whereas F-5'CTGGAGACCACTCCCATCCTTTCT-3T and R-5'-GATGTGGCCATCACATTCGTCAGA T-3' primers were utilized in the $\mathrm{PCR}$ reaction [2123]. According to their distinction in agarose gel electrophoresis, genotypes of PCR products were specified as D (deletion 190bp) and I (insertion $490 \mathrm{bp}$ ).

\section{Polymorphism analysis of MMP-2 (-1306 C/T) (rs243865) gene}

The PCR (Polymerase Chain Reaction) method was used to amplify the MMP-2 (-1306 $\mathrm{C} / \mathrm{T})$ gene specific region by through the primers F-5'-ATAGGGTAAACCTCCCCACATT-3' and R-5'-GGTAAAATGAGGCTGAGACCTG-3' [24]. In addition, polymorphic focus was specified by DNA sequence analysis by using the same primers.

\section{Statistical analysis}

Though the power analysis calculated that, with the polymorphism prediction of $30 \%$ in the CAD group and $5 \%$ in the control group, at least 27 people were needed for each group at $80 \%$ power and 95\% confidence interval, our study included 300 patients (200 patients and 100 healthy volunteers).

SPSS 17.0 program was used for performing, and the statistical significance level was set at $p<0.05$. The normality distribution of the dataset was investigated by Shapiro-Wilk test, whereas Pearson Chi-Square and Fisher's Exact Tests were compared in $2 \times 2$ eyes. Kruskal Wallis Test was used while non-parametric data were being analyzed for more than two groups.

\section{Results}

A total of 300 people, 200 of whom were patients $(66.67 \%)$ and 100 of whom were healthy volunteers $(33.33 \%)$, were included in the study; and of these individuals, 189 (63\%) were male, while $111(37 \%)$ were female. There were 14 patients $(7.00 \%)$ with CVD, $22(11.00 \%)$ with Chronic Obstructive Pulmonary Disease (COPD), 55 (27.50\%) with diabetes mellitus (DM), 65 (32.50\%) with Hypertension (HT) and $17(8.50 \%)$ with Hyperlipidemia (HL).

When the baseline laboratory and demographic data of the control and CAD groups were analyzed, the mean age of the CAD group turned out to be $68.26 \pm 11.83$. Moreover, the mean creatinine, WBC, hemoglobin, hs Troponin, and CKMB values were found to be $1.13 \pm 0.60 \mathrm{mg} / \mathrm{dl}, 9.79 \pm 4.36 \mathrm{~K} / \mu \mathrm{l}, 13.14 \pm 2.22$ $\mathrm{g} / \mathrm{dl}, 0.09 \pm 0.045 \mathrm{ug} / \mathrm{L}$, and $4.65 \pm 8.30 \mathrm{ug} / \mathrm{L}$, respectively. On the other hand, the mean age in the control group was $39.05 \pm 17.92$, whereas the mean creatinine, WBC, hemoglobin, hs Troponin, and CKMB values were calculated as $0.72 \pm 0.23 \mathrm{~g} / \mathrm{dl}, 10.33 \pm 9.31 \mathrm{~K} / \mu \mathrm{l}, 12.81 \pm 1.95$ $\mathrm{g} / \mathrm{dl}, 0.008 \pm 0.009 \mathrm{ug} / \mathrm{L}$, and $2.25 \pm 1.34 \mathrm{ug} / \mathrm{L}$, respectively (Table 1 ).

Given the between-group differences in the D/D, I/D and I/I ACE-1 genotypes frequency of the CAD cohort was $50 \%, 29 \%$, and $21 \%$, respectively whereas that of the healthy control cohort was $37 \%, 45 \%$ and $18 \%$, respectively. Our findings indicate that the groups differed significantly in relation to the ACE-1 genotypes $(p=0.021)$. Besides, the I/D genotype turned out to be more frequent in the healthy control group, while D/D genotype was observed to be more common in the CAD cohort. In terms of ACE-1 gene allele, the frequencies of $I$ and $D$ alleles in both cohorts did not reveal a significant difference $(p=0.314)$. In addition, the two groups did not manifest MMP-2 gene polymorphism (Table 2-4).

As far as the relationship between ACE-1 I-D polymorphism and laboratory parameters in the CAD group is concerned, the creatinine, CRP, WBC, Hemoglobin, hsTrop and CKMB values did not correlate with genotypes (Table 3). Likewise, the findings about ACE-1 genotypes 
Table 1. Baseline statistics of the groups

\begin{tabular}{lllll}
\hline & CAD & & & Control \\
& Mean \pm SD & Median $($ IQR) & Mean $\pm S D$ & Median $($ IQR) \\
\hline Age & $68.26 \pm 11.83$ & $70.00(62-77)$ & $39.05 \pm 17.92$ & $35.00(22-52.75)$ \\
Creatinine & $1.13 \pm 0.60$ & $0.96(0.8-1.26)$ & $0.72 \pm 0.23$ & $0.68(0.58-0.78)$ \\
WBC & $9.79 \pm 4.36$ & $8.84(6.95-11.75)$ & $10.33 \pm 9.31$ & $9.16(7.37-11.36)$ \\
Hb & $13.14 \pm 2.22$ & $13.05(11.8-14.72)$ & $12.81 \pm 1.95$ & $12.85(11.6-14.17)$ \\
hSTnT & $0.09 \pm 0.045$ & $0.02(0.013-0.043)$ & $0.008 \pm 0.009$ & $0.006(0.004-0.009)$ \\
CKMB & $4.65 \pm 8.30$ & $2.29(1.54-3.93)$ & $2.25 \pm 1.34$ & $2.11(1.16-3.1)$ \\
\hline
\end{tabular}

Hb. hemoglobin; hsTnT. high sensitive troponin T

WBC: White blood cell

CKMB: Creatine kinase MB

IQR: Inter Quantile Range

Table 2. Frequencies of ACE-1 insertion-deletion polymorphism and MMP-2 polymorphism in CAD and control groups

\begin{tabular}{|c|c|c|c|c|c|c|c|c|c|c|}
\hline \multirow{5}{*}{$\begin{array}{l}\text { ACE-1 Inser- } \\
\text { tion\&Dele- } \\
\text { tion }\end{array}$} & \multirow{4}{*}{$\begin{array}{l}\text { I/I } \\
I / D\end{array}$} & \multicolumn{4}{|c|}{ CAD Group } & \multicolumn{4}{|c|}{ Control Group } & \multirow{2}{*}{${ }^{*} p$} \\
\hline & & \multirow{3}{*}{$\begin{array}{l}n \\
42 \\
58\end{array}$} & \multirow{2}{*}{$\frac{\%}{(21.00)}$} & \multicolumn{2}{|c|}{ Allel frequence } & \multirow{2}{*}{$\frac{n}{18}$} & \multirow{2}{*}{$\frac{\%}{(18.00)}$} & \multicolumn{2}{|c|}{ Allel frequence } & \\
\hline & & & & I & 0.35 & & & I & 0.41 & \multirow{3}{*}{0.021} \\
\hline & & & $(29.00)$ & $\mathrm{D}$ & 0.65 & 45 & $(45.00)$ & $\mathrm{D}$ & 0.59 & \\
\hline & $\mathrm{D} / \mathrm{D}$ & 100 & $(50.00)$ & & & 37 & $(37.00)$ & & & \\
\hline \multirow{3}{*}{ MMP-2 } & wt/wt & 200 & $(100.00)$ & wt & 1.0 & 100 & $(100.00)$ & wt & 1.0 & \multirow{3}{*}{$N / E$} \\
\hline & $\mathrm{wt} / \mathrm{mt}$ & - & & $\mathrm{mt}$ & 0 & - & & $\mathrm{mt}$ & 0 & \\
\hline & $\mathrm{mt} / \mathrm{mt}$ & - & & & & - & & & & \\
\hline
\end{tabular}

${ }^{*} p$ values are derivated from Chi square Test

N/E means "not estimated"

wt: wild-type

mt: mutant-type

and laboratory parameters related to lipid profile in patients in CAD group yielded no significant relationship (Table 4). By contrast, the number of patients with hypertension in the D/D genotype was significantly higher than those with the other genotypes in terms of ACE-1 genotype and comorbid diseases $(p=0.035)$ (Table 5).

\section{Discussion}

Many reports in the relevant literature have dealt with the ACE gene polymorphism in patients with CAD, but these reports have come up with inconsistent results thus far. For instance, while some studies establish the $D / D$ gene polymorphism to be a risk factor in CAD patients $[16,17]$, others point to the I/D gene polymorphism as a factor contributing to $C A D$ [14]. In fact, there were cases in which some studies reported similar results between the patients and the control groups, or conversely, some others reported that the D/D gene polymorphism is protective $[17,18]$.

The study by Nakai et al. [16] revealed that the $A C E-1{ }^{*} D$ allele was higher in the CAD group than controls ( 0.58 vs. 0.42 respectively). Observed deletion polymorphisms found higher in ACE gene and it was related with ACE level, thereby increasing the CAD risk. However, no correlation was found between ACE-1 genotypes and cholesterol levels. One study, in which 171 patients with CAD and under 55 years old were compared with 134 healthy subjects with respect to gene polymorphism, reported that ACE-1 D/D genotype increased CAD risk by 2.3 times [17]. Another investigation into the effect of I/D genotype on mortality after MI suggested that $D / D$ genotype is related with lower cardiac mortality [18]. In a study on Asian Indians by Bhatti et al. [23], D/D genotype was observed to be more common higher in the CAD patients 

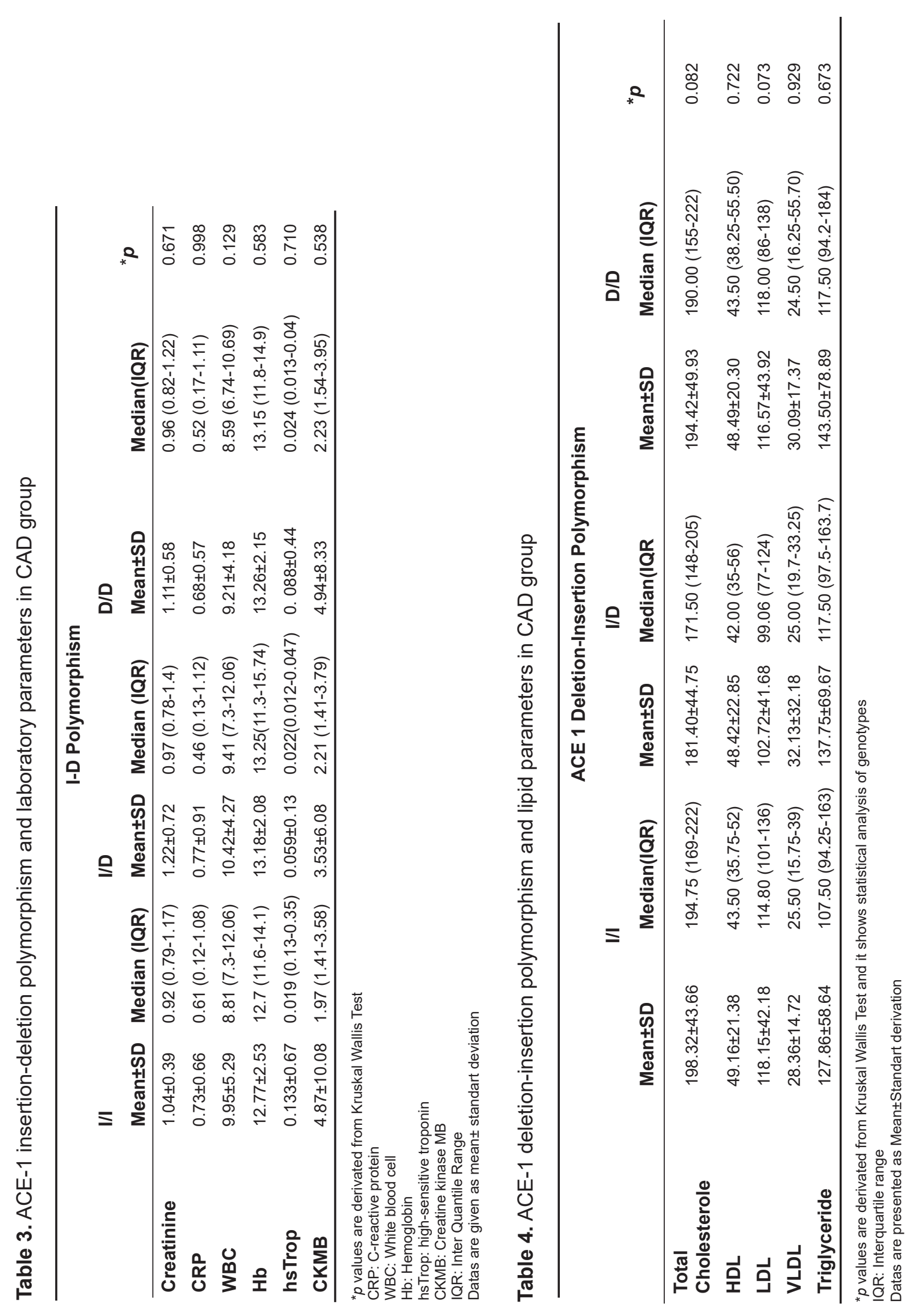
Table 5. Genotype and comorbid disease association in CAD group

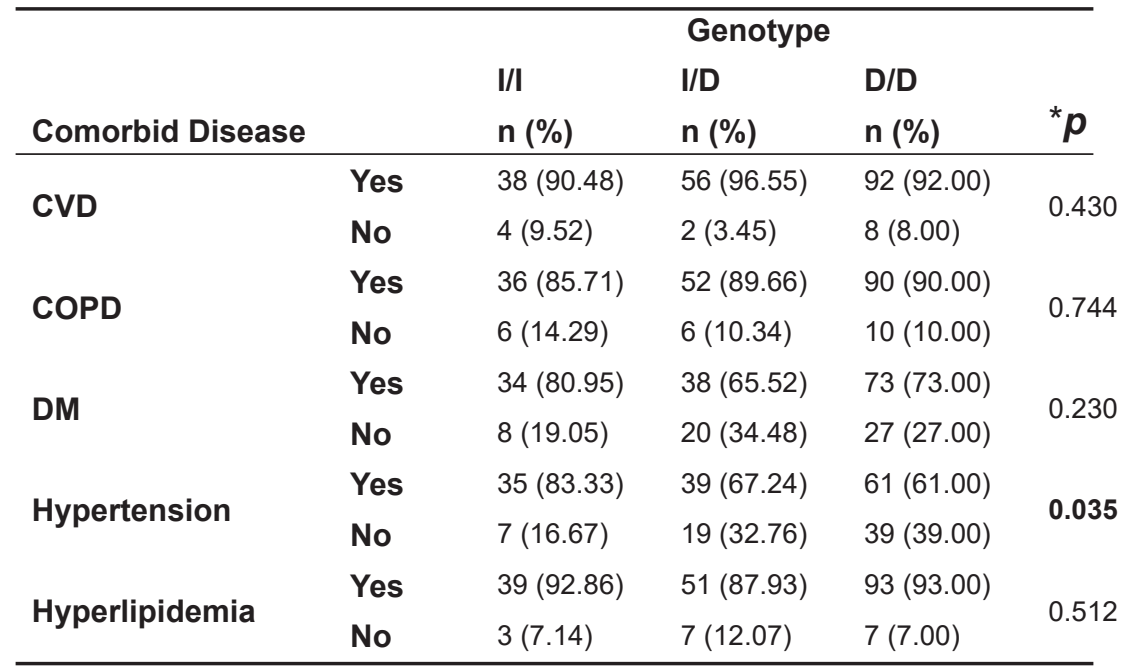

${ }^{*} p$ values are derivated from Chi Square Test

CVD, cardiovasculary disease; COPD, chronic obstructive pulmonary disease;

$\mathrm{DM}$, diabetes mellitus

than the controls, but no difference was noted in terms of I/D genotype frequency, just as no correlation emerged between ACE genotypes and biochemical parameters in patients with CAD. In a similar vein, Amara et al. [24] showed that the frequency of $D / D$ genotype remained higher in the CAD group than the control group. Including hospitalized patients in the coronary care unit and comparing these patients with the gene polymorphism with the control group, a study carried out in Turkey revealed that I/D gene polymorphism was more frequent in the patient group, while that of $D / D$ was more recurrent in the control group [14]. However, another study in Turkey consisting of 393 patients who underwent coronary angiography did not identify the D/D genotype as a risk factor [19]. On the other hand, our study found that the frequency of $D / D$ genotype was higher in the CAD group, whereas that of I/D was higher in the control group. In terms of genotype analysis, our findings are similar to those reported by Nakai et al. [16], Peterlin et al. [17], Fujisawa et al. [20], Bhatti et al. [23], and Amara et al. [24]. Different results were obtained from the studies conducted in our country by Eren et al. [14] and Tokgözoğlu et al. [19]. Similar to the studies by Nakai et al. [16] and Bhatti et al. [23], our study reports a lack of correlation between ACE-1 genotypes and laboratory parameters (lipid parameters and others).

Increased ACE levels in ACE gene variants or mutations or increased ACE activities on vascular tissue is assumed to play a role in the etiopathogenesis of CAD. As a matter of fact, just as Gupta et al. [25] and Borah et al. [26] establish D/D genotype to be associated with hypertension, our study suggests that HT frequency is higher in the D/D allele group than in the other groups.

So far, some of the studies have highlighted the importance of MMP-2 involved in the CAD development. Yet these studies have mainly investigated gene expression levels, but those focusing on gene polymorphism are relatively low.

Having evaluated MMP-1, MMP-3 and MMP-9 in addition to MMP-2 and reported no correlation between them, Gadherian et al. [27] did not establish a correlation between $\mathrm{Ml}$ and MMP-2 gene polymorphism. A study carried out in Turkey included 298 patients confirmed angiographically by pairing them with 299 healthy volunteers in terms of age and subsequently found no correlation between MMP-2 gene polymorphism and CAD development [28]. Similarly, this study reveals no correlation between CAD and MMP-2 (rs243865) gene polymorphism.

A range of limitations might have influenced the results of our study. For one thing, a subgroup analysis was not performed according to clinical parameters, such as coronary angiography findings and the severity of CAD. In addition, the fact that other factors which may constitute 
risk factors for CAD have not been considered within the framework of this study could be stated as a limitation.

As a result, the clinical evidence derived from the data in this study suggests a lack of marked relation between CAD and MMP-2 (rs243865) gene polymorphism. The I/D frequency of the genotype remained higher in the healthy individuals, while D/D genotype was more frequently found in the CAD group. Finally, the patients with $D / D$ genotype tend to bear greater risk for ischemic heart disease.

Conflict of interest: No conflict of interest was declared by the authors.

\section{References}

1. Vasků A, Goldbergová M, Izakovicová Hollá L, et al. A haplotype constituted of four MMP-2 promoter polymorphisms (-1575G/A, -1306C/T, -790T/G and $-735 \mathrm{C} / \mathrm{T})$ is associated with coronary triple-vessel disease. Matrix Biol 2004;22:585-591. https://doi. org/10.1016/j.matbio.2003.10.004

2. Alp E, Menevse S, Tulmac M, Yilmaz A, Yalcin R, Cengel A. The role of matrix metalloproteinase-2 promoter polymorphisms in coronary artery disease and myocardial infarction. Genet Test Mol Biomarkers 2011;15:193-202. https://doi.org/10.1089/ gtmb.2010.0113

3. Delgado Enciso I, Gonzalez Hernandez NA, Baltazar Rodriguez LM, et al. Association of matrix metalloproteinase-2 gene promoter polymorphism with myocardial infarction susceptibility in a Mexican population. J Genet 2009;88:249-252. https://doi. org/10.1007/s12041-009-0035-9

4. Dhillon OS, Khan SQ, Narayan HK, et al. Matrix metalloproteinase-2 predicts mortality in patients with acute coronary syndrome. Clin Sci (Lond) 2009;118:249257. https://doi.org/10.1042/CS20090226

5. Pérez Hernández N, Vargas Alarcón G, Martínez Rodríguez $\mathrm{N}$, et al. The matrix metalloproteinase 2-1575 gene polymorphism is associated with the risk of developing myocardial infarction in Mexican patients. J Atheroscler Thromb 2012;19:718-727. https://doi. org/10.5551/jat. 11817

6. Bostan C, Karcıer S. Anjiyotensin dönüştürücü enzim geni polimorfizmi ve kardiyovasküler hastalıklar. Türk Kardiyol Dern Arş 2002;30:441-448.

7. Agerholm Larsen B, Nordestgaard BG, Tybjaerg Hansen A. ACE gene polymorphism in cardiovascular disease. Meta-analyses of small and large studies in whites. Arterioscler Thromb Vasc Biol 2000;20:484492. https://doi.org/10.1161/01.atv.20.2.484
8. Lindpaintner K, Pfeffer MA, Kreutz R, et al. A prospective evaluation of an angiotensin-converting-enzyme gene polymorphism and the risk of ischemic heart disease. $\mathrm{N}$ Engl J Med 1995;332:706-712. https://doi.org/10.1056/ NEJM199503163321103

9. Cambien F, Poirier O, Lecerf L, et al. Deletion polymorphism in the gene for angiotensin-converting enzyme is a potent risk factor for myocardial infarction. Nature 1992;359:641-644. https://doi. org/10.1038/359641a0

10. Ko YL, Ko YS, Wang SM, et al. Angiotensinogen and angiotensin-I converting enzyme gene polymorphisms and the risk of coronary artery disease in Chinese. Hum Genet 1997;100:210-214. https://doi.org/10.1007/ s004390050492

11. Akbulut $\mathrm{T}$, Bilsel $\mathrm{T}$, Uyarel $\mathrm{H}$, et al. Anjiyotensin dönüştürücü enzim gen polimorfizminin erken koroner arter hastalığı gelişimindeki rolü. Türk Kardiyol Dern Arş 2004;32:23-27.

12. Heart Outcomes Prevention Evaluation Study Investigators, Yusuf $S$, Sleight $P$, et al. Effects of an angiotensin-converting-enzyme inhibitor, ramipril, on cardiovascular events in high-risk patients. N Engl J Med 2000;342:145-153. https://doi.org/10.1056/ NEJM200001203420301

13. Nakahara K, Matsushita S, Matsuoka H, et al. Insertion/ deletion polymorphism in the angiotensin-converting enzyme gene affects heart weight. Circulation 2000;101:148-151. https://doi.org/10.1161/01. cir.101.2.148

14. Eren Z, Kantarcı G, Kurt T, et al. Association of Angiotensin Converting Enzyme Polymorphism and the Risk of Myocardial Infarction in Turkish Patients. Türkiye Tıp Dergisi 2002;9:95-101.

15. Pfohl $M$, Koch $M$, Prescod $S$, Haase KK, Häring $\mathrm{HU}$, Karsch KR. Angiotensin l-converting enzyme gene polymorphism, coronary artery disease and myocardial infarction. An angiographically controlled study. Eur Heart J 1999;20:1318-1325. https://doi.org/10.1053/ euhj.1999.1543

16. Nakai $\mathrm{K}$, Itoh $\mathrm{C}$, Miura $\mathrm{Y}$, et al. Deletion polymorphism of the angiotensin l-converting enzyme gene is associated with serum ACE concentration and increased risk for CAD in the Japanese. Circulation 1994;90:2199-2202. https://doi.org/10.1161/01.cir.90.5.2199

17. Peterlin B, Petrovic D, Zorc M, Keber I. Deletion/insertion polymorphism in the angiotension-converting enzyme gene as a risk factor in the Slovenian patients with coronary heart disease. Pflugers Arch 2000;439:40-41. https://doi.org/10.1007/s004240000084

18. Tokunaga S, Tsuji H, Nishiue $T$, et al. Lower mortality in patients with the DD genotype of the angiotensinconverting enzyme gene after acute myocardial infarction. Acta Cardiol 2001;56:351-355. https://doi. org/10.2143/AC.56.6.2005698 
19. Tokgözoğlu SL, Alikaşifoğlu M, Unsal, et al. Methylene tetrahydrofolate reductase genotype and the risk and extent of coronary artery disease in a population with low plasma folate. Heart 1999;81:518-522. https://doi. org/10.1136/hrt.81.5.518

20. Fujisawa $T$, Ikegami $H$, Shen $G Q$, et al. Angiotensin I-converting enzyme gene polymorphism is associated with myocardial infarction, but not with retinopathy or nephropathy, in NIDDM. Diabetes Care 1995;18:983985. https://doi.org/10.2337/diacare.18.7.983

21. Rigat B, Hubert C, Corvol P, Soubrier R. PCR detection of the insertion/deletion polymorphism of the human angiotensin converting enzyme gene (DCP1) (dipeptidyl carboxypeptidase 1). Nucleic Acids Res 1992;20:1433. https://doi.org/10.1093/nar/20.6.1433-a

22. Gonzalez Hernandez NA, Millan Guerrero RO, Ceja Espiritu G, et al. A polymorphism in the matrix metalloproteinase-2 (MMP-2-1306T>C) gene promoter is associated with high risk of ischemic stroke in hypertensive patients. Genes Genom 2008;30:533540.

23. Bhatti GK, Bhatti JS, Vijayvergiya R, Singh B. Implications of ACE (I/D) Gene Variants to the Genetic Susceptibility of Coronary Artery Disease in Asian Indians. Indian J Clin Biochem 2017;32:163-170. https://doi.org/10.1007/s12291-016-0588-3

24. Amara A, Mrad M, Sayeh A, et al. Association of FV G1691A polymorphism but not A4070G with coronary artery disease. Clin Appl Thromb Hemost 2018;24:330337. https://doi.org/10.1177/1076029617744320

25. Gupta S, Agrawal BK, Goel RK, et al. Angiotensinconverting enzyme gene polymorphism in hypertensive rural population of Haryana, India. J Emerg Trauma Shock 2009;2:150-154. https://doi.org/10.4103/09742700.55323

26. Borah PK, Shankarishan P, Hazarika NC, Mahanta J. Hypertension subtypes and angiotensin converting enzyme (ACE) gene polymorphism in Indian. J Assoc Physicians India 2012;60:15-17.

27. Ghaderian SMH, Akbarzadeh Najar R, Tabatabaei Panah AS. Genetic polymorphisms and plasma levels of matrix metalloproteinases and their relationships with developing acute myocardial infarction. Coron Artery Dis 2010;21:330-335. https://doi.org/10.1097/ MCA.0b013e32833ce065

28. Alp E, Menevse S, Tulmac M, Yilmaz A, Yalcin R, Cengel $A$. The role of matrix metalloproteinase-2 promoter polymorphisms in coronary artery disease and myocardial infarction. Genet Test Mol Biomarkers 2011;15:193-202. https://doi.org/10.1089/ gtmb.2010.0113
Ethical approval: Approval was obtained from Pamukkale University Non-Interventional Clinical Research Ethics Committee (with the Board Decision dated 06.03.2018 and numbered 17126).

Funding: This study was supported by Scientific Research Projects Coordination Unit of Pamukkale University (PAU-BAP) with the project numbered as 2018TIPF027.

\section{Authors' contributions to the article}

I.T., A.K. and K.G. constructed the main idea and hypothesis of the study. A.K., A.Y. and R.S. developed the theory and revised the material method section. K.G., R.S. and A.Y. evaluated the data in the results section. The discussion part of the article was written by K.G., A.K, I.T. and A.Y. reviewed and made the necessary corrections and approved the study. In addition, all authors discussed the entire study and approved its final version. 